\title{
TIME-RESOLVED FLUORESCENCE SPECTROSCOPY OF THE HEART TISSUES
}

\author{
J. Venius ${ }^{\text {a }}$, S. Bagdonas ${ }^{\mathrm{b}}$, E. Žurauskas ${ }^{\mathrm{c}}$, and R. Rotomskis ${ }^{\mathrm{a}, \mathrm{b}}$ \\ ${ }^{a}$ Biomedical Physics Laboratory of Institute of Oncology, Vilnius University, Baublio 3B, LT-08406 Vilnius, \\ Lithuania \\ E-mail: jonas.venius@vuoi.lt \\ ${ }^{b}$ Biophotonics Group of Laser Research Centre, Vilnius University, Sauletekio 9, LT-10222 Vilnius, Lithuania \\ 'Medical Faculty of Vilnius University, Čiurlionio 21, LT-03100 Vilnius, Lithuania
}

Received 20 October 2011; revised 13 December 2011; accepted 13 December 2011

\begin{abstract}
During the heart surgery there is a possibility to harm the conduction system of the heart (HCS), which may cause dangerous obstruction of the heart functionality. The muscular origin makes it complicated to distinguish HCS from the surrounding tissues; therefore, there is an immense necessity to visualise HCS during the operation time. Optical methods carry information about intrinsic properties of the tissue and provide the unique possibility to study the objects non-invasively. The experiments were performed on the human heart tissue specimens ex vivo. HCS, myocardium (MC), and connective tissue (CT) were preliminary marked by a pathologist and histologically approved after the spectral measurements. The spectrometer FLS920 (Edinburgh Instruments) was used for steady state and time-resolved fluorescence registration. Fluorescence was exited using a $405 \mathrm{~nm}$ pulsed laser. Spectral analysis revealed that at least three fluorophores are responsible for the emission in the region of $430-550 \mathrm{~nm}$. According to the lifetimes, the fluorescing constituents in all tissues should be the same. The fractional components of fluorescence intensity revealed a similar composition of MC and HCS; however, quantitative differences were observed between HCS and CT.
\end{abstract}

Keywords: heart, myocardium, time-resolved fluorescence

PACS: 87.19.Hh, 87.64.kv, 87.85.Pq

\section{Introduction}

Cardiac disorders still remain the leading cause of mortality and morbidity. In numerous cases the surgery is the only way to eliminate the source of heart malfunction; however, during the surgical intervention there is a possibility to harm the conduction system of the heart (HCS), which may cause dangerous obstruction of heart functionality. HCS is a type of the muscular tissue where a heartbeat signal originates and initiates the contraction of the ventricles. The muscular origin makes it complicated to distinguish HCS from the surrounding tissues; therefore, there is an immense necessity for a express method to visualise HCS during the operation time.

Optical methods carry information about intrinsic properties of the tissue and provide a unique possibility to study the objects quickly and non-in- vasively. Fluorescence spectroscopy techniques are already used in different areas of medicine for diagnosis and visualisation purposes [1-3]. Fluorescence reflects the general composition of the tissue and depends mostly on the present fluorophores; however, since many of the intrinsic fluorophores in biological tissues have the overlapping spectra, it is difficult to identify the selective excitation region for the fluorescence-based discrimination between two different tissues $[4,5]$. Another rapidly evolving optical technique employs fluorescence lifetime measurements. Fluorescence lifetime is the characteristic average time that a fluorophore spends in the excited state following excitation from its ground energy level. Fluorescence lifetime varies with the molecular environment but usually does not depend on fluorophore concentration or signal attenuation caused by absorption or scattering [5-7]. Thus, fluorophores with overlapping fluorescence 
spectra could be distinguished by different fluorescence lifetimes. The time-resolved measurements can also help to overcome a common spectroscopy problem of the variation in the measured signal intensity at different spots caused by uneven fluorescence excitation/collection conditions. Furthermore, the sensitivity of the fluorescence lifetime to various parameters of the biological microenvironment of a fluorophore (including $\mathrm{pH}$, ion concentration and binding, enzymatic activity, temperature) allows these variables to be analysed as well [8].

Fluorescence spectroscopy techniques have been chosen to detect elastin, collagen, lipids, and other sources of autofluorescence in normal and diseased arterial walls [9-14]. Different parts of the heart have also been shown to possess different fluorescence intensities [15-17]. More recently, the application of steady state fluorescence techniques to the ex vivo identification of different types of the heart tissues, including HCS, has been reported $[18,19]$. The main fluorophores in the heart were identified as collagen and elastin [17, 19-22], and it was inferred that the observed differences in fluorescence intensity are primarily determined by uneven amounts and the specific organisation of structural proteins rather than by the presence of specific fluorophores [19]. Since none of the types of the heart tissues possess distinct fluorescence spectra, the discrimination between them directly depends on the measurement conditions. The earlier proposed method employs the ratio of autofluorescence (AF) intensities being measured at the same investigation spot [19], thus eliminating the effect of uneven excitation/collection conditions. The unambiguous differentiation of the HCS from two other types of the heart tissue has been demonstrated ex vivo using this method, provided there is a fair possibility to normalise the PL signal for the individual-based variation in spectral properties of the heart. However, the isolating layer that surrounds HCS is made of collagen and elastin fibres, the same components as CT, which affects the spectroscopic contrast between HCS and CT. On the other hand, this layer could possess a unique structural organisation because of the specific function of HSC in the heart. The different structure could yield the specific fluorescence lifetimes. In such case the combined registration of both fluorescence and fluorescence lifetime signals could be employed to improve the accuracy of heart tissue differentiation.
The aim of our study was to investigate the different heart tissues by means of time-resolved fluorescence spectroscopy, and also to determine the number of fluorescing constituents composing the registered steady state fluorescence spectra and to calculate the fractional components of the fluorescence intensity that could help to determine the relative amounts of these components in different heart tissues, which could be useful for its differentiation.

\section{Materials and methods}

The experiments were performed on the specimens prepared from a single human heart. The samples of $2-3$ centimetres in size were obtained at autopsy (12-24 h post mortem) by a pathologist in the $\mathrm{Na}-$ tional Centre of Pathology according to the methodology described earlier [18]. Preparations were fixed in a $10 \%$ neutral buffered formalin solution immediately after excision and kept in the dark at $4{ }^{\circ} \mathrm{C}$ prior to the measurements. Spectroscopic studies were carried out on the diagnostically most important types of the heart tissue: HCS, myocardium (MC), and connective tissue (CT). The specimen that contained HCS was prepared from the left branch of His bundle. The specimen for MC was prepared from the ventricles, and the CT specimen was prepared from the aorta. The location of particular tissue was marked on each specimen by the pathologist. Steady state fluorescence spectra of HCS, CT, and MC have been measured from multiple places on three prepared specimens. In total, 7 fluorescence spectra were registered from each type of specimen.

The spectroscopic measurements were performed by means of a spectrofluorimeter FLS920 (Edinburgh Instruments). The excitation arm of the instrument was equipped with a $450 \mathrm{~W}$ xenon lamp and a double grating monochromator to select the appropriate wavelength for the steady state fluorescence excitation as well as with a pulsed diode laser $(\lambda=405 \mathrm{~nm}$, pulse width $=66.9 \mathrm{ps})$, which has been used for the time-resolved measurements. A special solid sample holder (Edinburgh Instruments) was installed in the place of a standard cuvette holder in order to measure the fluorescence spectra and the fluorescence lifetimes of the heart specimens. To prevent the tissues from drying out, the specimens were fixed between quartz slides and 
mounted on the holder. It was assumed that the measurement conditions arranged in this manner did not change for different heart tissues, thus allowing to compare the absolute intensities of the registered fluorescence spectra. The detection arm of the spectrofluorimeter was also equipped with a double grating monochromator and a thermoelectrically cooled photomultiplier tube. Lifetime measurements were performed using the time correlated single photon counting (TCSPC) methodology. The fluorescence decay was measured in the spectral region of $430-550 \mathrm{~nm}$ with a $5 \mathrm{~nm}$ step. The fluorescence quantum efficiency of the heart tissues is very low; therefore, 1000 counts were collected in the peak channel. The fluorescence data were automatically corrected for the instrument response by the factory preinstalled correction files.

The fluorescence decay lifetimes $(\tau)$ and the fractional components of fluorescence intensity $(F)$ were calculated using FAST software (Edinburgh Instruments). An instrument response function was measured from the polymer microspheres (Thermo Scientific) suspended in water.

The steady state fluorescence spectra of HCS, $\mathrm{CT}$, and MC were registered in the region of 430$550 \mathrm{~nm}$ under a $405 \mathrm{~nm}$ excitation.

\section{Results and discussion}

The averaged fluorescence spectra of every tissue are shown in Fig. 1 together with the standard

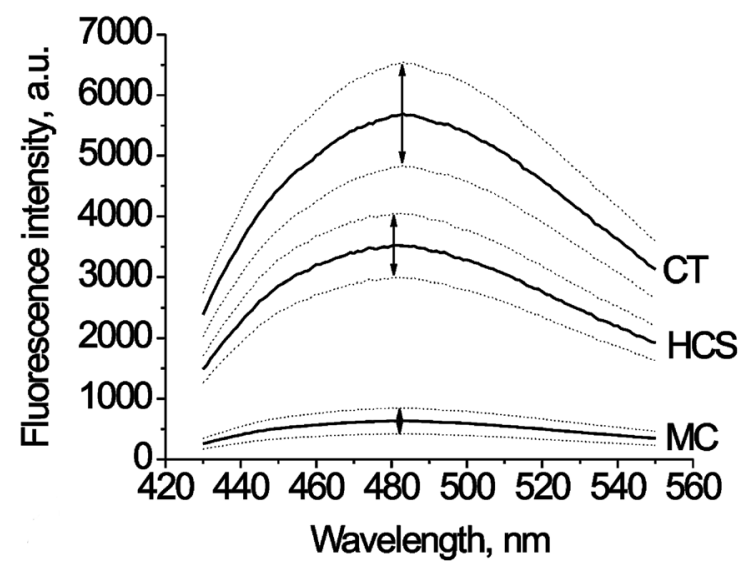

(a) deviation ranges. All spectra are composed of the broad band with the peak at around $482 \mathrm{~nm}$. The spectral shape is almost identical for all the tissues (Fig. 1(b)) implying that the fluorophores in these tissues should be the same. Then the observed differences in intensity (Fig. 1(a)) could be the result of uneven amounts of the fluorophores or their different quantum yields that could be affected by variations in the surrounding microenvironment. The finding that the fluorescence intensity registered under the same conditions is different for CT, HCS, and MC could be useful for the differentiation between these tissues. However, it is not always possible to maintain exactly the same measurement conditions for all spots of interest in the biological system. Uneven excitation/collection conditions can distort or blur the registered intensity differences even though the tissues were the same. Such possibly confusing situation could be evaded by accomplishing the time-resolved measurements.

The experimental data of the HCS fluorescence decay approximated by one and two exponentials are presented in Fig. 2. The fitted curves do not correspond to the measured decay that additionally could be demonstrated by the residuals and the increased $\chi^{2}$ value. This indicates that more than one or two different components are forming the shape of the fluorescence decay curve.

The experimental data of MC, HCS, and CT fitted by three exponentials are presented in Fig. 3. The fitted decay curves closely correlate with the

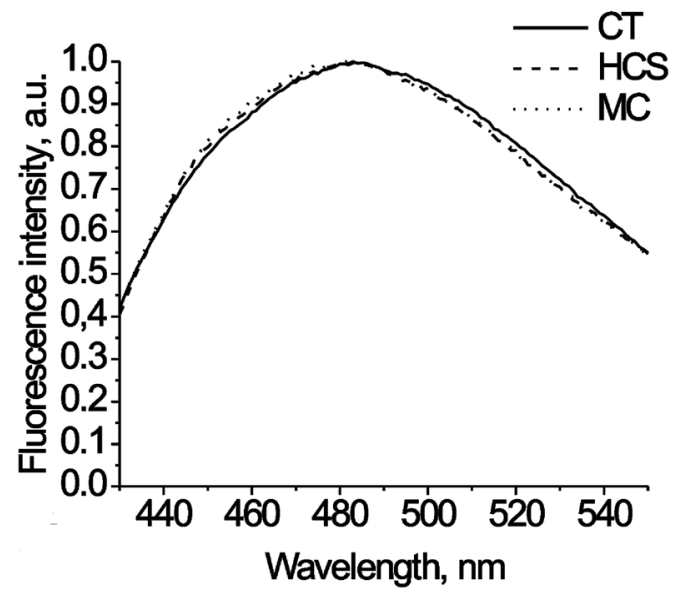

(b)

Fig. 1. (a) The mean fluorescence spectra of CT, MC, and HCS registered under excitation at $405 \mathrm{~nm}$. The dotted lines represent the standard deviation values. (b) The normalised mean fluorescence spectra. 

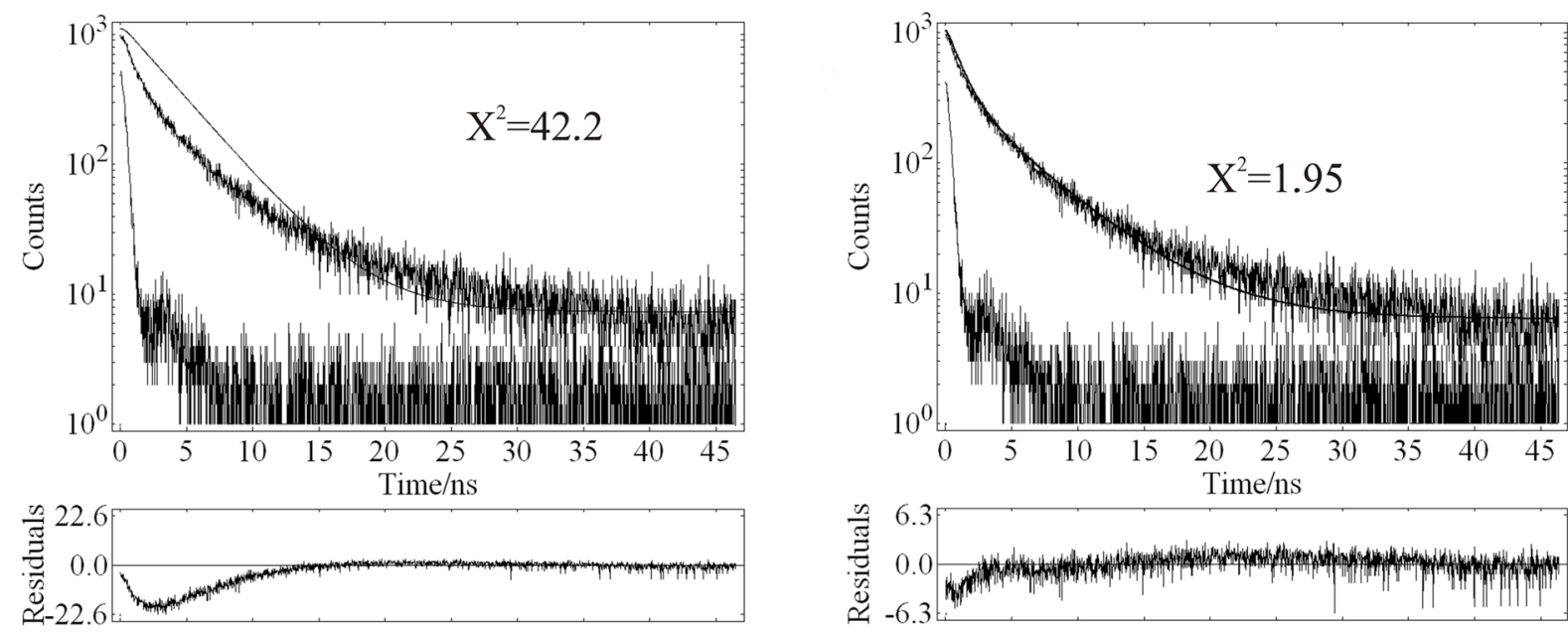

(a)

(b)

Fig. 2. Fluorescence decay approximated by one (a) and two (b) exponentials.

(a)
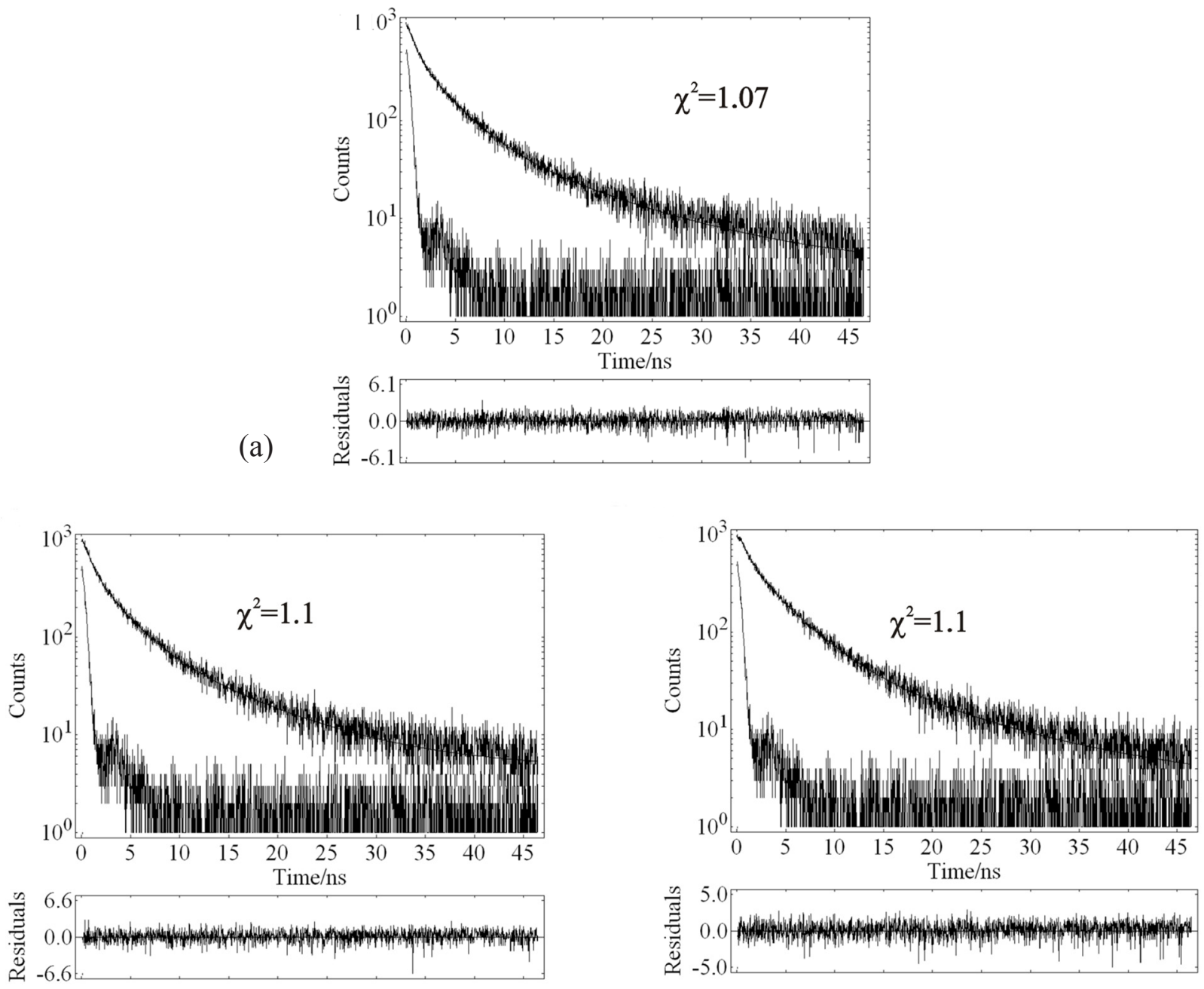

(b)

(c)

Fig. 3. Fluorescence intensity decay registered at $482 \mathrm{~nm}$ for MC (a), HCS (b), and CT (c). 
measured values as this could be seen from residuals and $\chi^{2}$. Thus, according to the mathematical analysis, the fluorescence intensity decay that has been registered at $482 \mathrm{~nm}$ for all three tissue types can be accurately approximated by three exponentials indicating that at least three fluorophores are responsible for the fluorescence signal. The lifetimes of every tissue did not change throughout the spectral region of 430-550 $\mathrm{nm}$.

The average lifetimes of the fluorophores calculated through the whole spectral region (430$550 \mathrm{~nm}, n=25)$ and the standard deviations are presented in Table 1 . The significance of the difference between averaged lifetimes of HCS and other tissues was evaluated using a paired $t$-test for the null hypothesis $\tau^{\mathrm{HCS}}-\tau^{\mathrm{CT}}=0$ and $\tau^{\mathrm{HCS}}-\tau^{\mathrm{MC}}=0$.

The main fluorophores in the heart tissue were shown to be collagen and elastin [17, 19-22]; however, collagen is found in the heart tissues in several forms. The cardiac collagen of extracellular matrix consists of $85 \%$ of collagen type I [23]. In addition to collagen I, other fibril forming collagen types found in the heart are collagen III and collagen V [24]. The collagen in a valve, which is composed mostly of the connective tissue, consists of collagen I (74\%), collagen III (24\%) and collagen V (2\%) [25]. Therefore, the fluorophores that mostly contribute to the registered fluorescence decay in all three types of tissue could be identified as elastin, collagen I and collagen III. The fluorescence spectrum of elastin overlaps with the fluorescence spectra of collagen III; therefore, it could be hardly distinguished by applying only techniques of steady state spectroscopy.
To determine the contribution of each fluorophore in the fluorescence spectra, the fractional components of the fluorescence intensity $(F)$ have been calculated. The average contribution values of the first, the second, and the third constituent to the fluorescence spectra measured in the spectral region of $430-550 \mathrm{~nm}$ are presented in Table 2. The significance of the difference between averaged contribution values of HCS and other tissues was evaluated using a paired $t$-test for the null hypothesis $F^{\mathrm{HCS}}-F^{\mathrm{CT}}=0$ and $F^{\mathrm{HCS}}-F^{\mathrm{MC}}=0$.

The contribution did not change significantly through the whole spectral region indicating that the fluorophores responsible for the fluorescence in this region do not change their relative amounts significantly. It has to be noted that the fractional components reflect the contribution of a particular fluorophore to the registered fluorescence spectra upon particular excitation and emission wavelengths; nevertheless, it could be used to compare the relative composition of the fluorophores in the heart tissues. Muscular type tissues (MC and HCS) had a very similar composition of fluorophores, while statistically significant differences were observed between HCS and CT (see Table 2, constituent F1). The first constituent is present in larger amounts in an elastic-type tissue (HCS), whereas a stiff tissue like CT contains larger amounts of the second constituent. According to this analysis, the first constituent corresponds to elastin, the second to collagen I, and the third to collagen III.

The estimation of the time-resolved autofluorescence data on the lifetimes and fractional

Table 1. The average lifetimes (ns) and their standard deviations obtained for different heart tissues. $P\left(\mathrm{H}_{0}=0\right)$ are values of significance levels for the null hypothesis.

\begin{tabular}{c|c|c|c|c|c}
\hline & MC & $P\left(\mathrm{H}_{0}=0\right)$ & HCS & $P\left(\mathrm{H}_{0}=0\right)$ & CT \\
\hline$\tau_{1}$ & $0.7 \pm 0.1$ & 0.07 & $0.7 \pm 0.1$ & $2.9 \cdot 10^{-5}$ & $0.9 \pm 0.1$ \\
\hline$\tau_{2}$ & $3.1 \pm 0.2$ & 0.19 & $3.2 \pm 0.3$ & $2.2 \cdot 10^{-4}$ & $3.5 \pm 0.4$ \\
\hline$\tau_{3}$ & $10.6 \pm 1$ & 0.94 & $10.7 \pm 1.2$ & 0.84 & $10.7 \pm 1.7$ \\
\hline
\end{tabular}

Table 2. The relative contribution of different fluorophores to the fluorescence spectra. $\mathrm{P}\left(\mathrm{H}_{0}=0\right)$ are values of significance levels for the null hypothesis.

\begin{tabular}{c|c|c|c|c|c}
\hline & MC & $P\left(\mathrm{H}_{0}=0\right)$ & HCS & $P\left(\mathrm{H}_{0}=0\right)$ & CT \\
\hline$F 1$ & $27 \pm 3$ & 0.09 & $28 \pm 2$ & $3.34 \cdot 10^{-8}$ & $20 \pm 4$ \\
\hline$F 2$ & $46 \pm 2$ & 0.57 & $47 \pm 2$ & $1.51 \cdot 10^{-5}$ & $51 \pm 4$ \\
\hline$F 3$ & $27 \pm 3$ & 0.08 & $25 \pm 3$ & 0.01 & $29 \pm 5$ \\
\hline
\end{tabular}


components yielded statistically unreliable difference between these values from HCS and MC. Therefore, these two tissues could not be distinguished by fluorescence decay analysis only. On the other hand, some differences were observed between the time-resolved data from CT and HCS. The decay constants $\tau_{1}$ and $\tau_{2}$ of HCS appeared to be significantly different from those of CT (Table 1 ). The relative constituents $F 1-F 3$ of the spectral composition were also found to be significantly different between HCS and CT (Table 2). Since the fibrils of HCS are usually surrounded by the connective tissue, and the absolute intensity of the fluorescence tends to vary from heart to heart, the contrast between these two tissues observed using only the intensity ratios of the measured fluorescence could be reduced [19]. It seems that in such cases the differentiation accuracy could be additionally improved by performing time-resolved measurements that showed the potential of differentiation between HCS and CT on the basis of the time-domain data.

\section{Conclusions}

The time-resolved spectroscopy revealed that at least three constituents are responsible for the fluorescence of HCS, CT, and MC in the spectral region of 430-550 $\mathrm{nm}$ under excitation at $405 \mathrm{~nm}$. The lifetimes of every tissue did not change throughout the measured region, indicating that the composing fluorophores are the same. The three autofluorescence lifetimes being attributed to HCS and MC did not show any statistically significant difference, whereas the two shorter $\left(\tau_{1}\right.$ and $\tau_{2}$ ) of HCS appeared to be significantly different from those of CT. The fractional components of fluorescence intensity did not reveal any significant difference in the composition of muscular type tissues, HCS and MC. On the other hand, the relative spectral composition (constituents $F 1-F 3$ ) of CT differed significantly from that of HCS. The observed differences could be explained by relatively larger amounts of elastin present in HCS, and of collagen in CT. We suppose that the revealed differences could be used for an optical method supplementary to the earlier proposed differentiation procedure [19] in order to enhance the contrast between HCS and CT.

\section{Acknowledgements}

This work was supported by the Research Council of Lithuania under grant No. LIG-25/2010.

\section{References}

[1] F. Leblond, S.C. Davis, P.A.Valdés, and B.W. Poguea, Pre-clinical whole-body fluorescence imaging: Review of instruments, methods and applications, J. Photochem. Photobiol. B 98(1), 77-94 (2010).

[2] N. Ramanujam, Fluorescence spectroscopy of neoplastic and nonneoplastic tissues, Neoplasia 2(1-2), 89-117 (2000).

[3] T. Glanzmann, J.P. Ballini, H. Van den Bergh, and G. Wagnieres, Time-resolved spectrofluorometer for clinical tissue characterization during endoscopy, Rev. Sci. Instrum. 70(10), 4067-4077 (1999).

[4] G.A. Wagnieres, W.M. Star, and B.C. Wilson, In vivo fluorescence spectroscopy and imaging for oncological applications, J. Photochem. Photobiol. 68(5), 603-632 (1998).

[5] M.-A. Mycek and B.W. Pogue (eds.), Handbook of Biomedical Fluorescence (Marcel Dekker, New York, 2003).

[6] J.R. Lakowicz, Principles of Fluorescence Spectroscopy, 2nd ed. (Kluwer Academic / Plenum, New York, 1999).

[7] R. Cubeddu, D. Comelli, C. D’Andrea, P. Taroni, and G. Valentini, Time-resolved fluorescence imaging in biology and medicine, J. Phys. D 35(9), R61-R76 (2002).

[8] L. Marcu, Fluorescence lifetime in cardiovascular diagnostics, J. Biomed. Opt. 15(1), 011106 (2010).

[9] P.R. Moreno and J.E. Muller, Identification of highrisk atherosclerotic plaques: a survey of spectroscopic methods, Curr. Opin. Cardiol. 17(6), 638647 (2002).

[10] Y. Honda and P.J. Fitzgerald, Frontiers in intravascular imaging technologies, Circulation 117(15), 2024-2037 (2008).

[11]R. Richards-Kortum and E. Sevick-Muraca, Quantitative optical spectroscopy for tissue diagnosis, Annu. Rev. Phys. Chem. 47, 555-606 (1996).

[12]T.G. Papazoglou, W.Q. Liu, A. Katsamouris, and C. Fotakis, Laser-induced fluorescence detection of cardiovascular atherosclerotic deposits via their natural emission and hypocrellin (Ha) probing, J. Photochem. Photobiol. B 22(2), 139-144 (1994).

[13]J.J. Baraga, R.P. Rava, P. Taroni, C. Kittrell, M. Fitzmaurice, and M.S. Feld, Laser-induced fluorescence spectroscopy of normal and atherosclerotic human aorta using $306-310 \mathrm{~nm}$ excitation, Lasers Surg. Med. 10(3), 245-261 (1990).

[14] A.L. Bartorelli, M.B.Leon, Y.Almagor,L.G. Prevosti, J.A. Swain, C.L. McIntosh, R.F. Neville, M.D. House, and R.F. Bonner, in vivo human atherosclerotic 
plaque recognition by laser-excited fluorescence spectroscopy, J. Am. Coll. Cardiol. 17(6), B160B168 (1991).

[15]M. Perk, G.J. Flynn, S. Gulamhusein, Y. Wen, C. Smith, B. Bathgate, J. Tulip, N.A. Parfrey, and A. Lucas, Laser induced fluorescence identification of sinoatrial and atrioventricular nodal conduction tissue, Pacing Clin. Electrophysiol. 16, 1701-1712 (1993).

[16] G.E. Kochiadakis, S.I. Chrysostomakis, M.D. Kalebubas, G.M. Filippidis, I.G. Zacharakis, and T.G. Papazoglou, The role of laser-induced fluorescence in myocardial tissue characterization, Chest 120, 233-239 (2001).

[17]G. Filippidis, G. Zacharakis, G.E. Kochiadakis, S.I. Chrysostomakis, P.E. Vardas, C. Fotakis, and T.G. Papazoglou, Ex vivo laser-induced fluorescence measurements of lamb and human heart tissue, Laser Phys. 13(5), 769-772 (2003).

[18]S. Bagdonas, E. Žurauskas, G. Streckyte, and R. Rotomskis, Spectroscopic studies of the human heart conduction system ex vivo: implication for optical visualization, J. Photochem. Photobiol. B 92(2), 128-134 (2008).

[19]J. Venius, S. Bagdonas, E. Žurauskas, and R. Rotomskis, Visualization of human heart conduction system by means of fluorescence spectroscopy, J. Biomed. Opt. 16, 107001 (2011); doi:10.1117/1.3631786.
[20]A.M. Nilsson, D. Heinrich, D. Olajos, and S. Andersson-Engels, Near infrared diffuse reflection and laser-induced fluorescence spectroscopy for myocardial tissue characterisation, Spectrochim. Acta A 53, 1901-1912 (1997).

[21] L. Marcu, W.S. Grundfest, and M.C. Fishbein, Timeresolved laser-induced fluorescence spectroscopy for staging atherosclerotic lesions, in: Handbook of Biomedical Fluorescence, eds. M.-A. Mycek and B.W. Pogue (Marcel Dekker Inc., New York, Basel, 2003) pp. 397-430.

[22]J. Venius, D. Labeikytè, E. Žurauskas, V. Strazdaité, S. Bagdonas, and R. Rotomskis, Investigation of human heart tissue extracts by spectroscopic methods, Biologija 3, 53-58 (2006).

[23] S.M. Weis, J.L. Emery, K.D. Becker, D.J.Jr. McBride, J.H. Omens, and A.D. McCulloch, Myocardial mechanics and collagen structure in the osteogenesis imperfecta murine (oim), Circulation Res. 87, 663669 (2000).

[24] G.M. Fomovsky, S. Thomopoulos, and J.W. Holmes, Contribution of extracellular matrix to the mechanical properties of the heart, J. Mol. Cell. Cardiol. 48(3), 490-496 (2010).

[25] W.G. Cole, D. Chan, A.J. Hickey, and D.E. Wilcken, Collagen composition of normal and myxomatous human mitral heart valves, Biochem. J. 219(2), 451-460 (1984).

\title{
ŠIRDIES AUDINIŲ TYRIMAI FLUORESCENCINE LAIKINĖS SKYROS SPEKTROSKOPIJA
}

\author{
J. Venius ${ }^{a}$, S. Bagdonas ${ }^{b}$, E. Žurauskas ${ }^{c}$, R. Rotomskis ${ }^{\text {a,b }}$ \\ ${ }^{a}$ Vilniaus universiteto Onkologijos instituto Biomedicininès fizikos laboratorija, Vilnius, Lietuva \\ ${ }^{b}$ Vilniaus universiteto Tyrimu centro biofotonikos grupe, Vilnius, Lietuva \\ ${ }^{c}$ Vilniaus universiteto Medicinos fakultetas, Vilnius, Lietuva
}

\section{Santrauka}

Širdies operaciju metu yra galimybè pažeisti širdies laidžiąją sistemą (ŠLS) ir sukelti nepataisomus širdies veiklos sutrikimus. Dèl raumeninès ŠLS kilmès ją sunku vizualiai atskirti nuo aplinkinių širdies audinių, todèl reikalingas metodas, padèsiantis atskirti ŠLS operacijų metu. Optiniai metodai yra neinvaziniai tyrimo būdai, kurių metu registruojami audinio optiniai parametrai, atspindintys kiekybinę bei kokybinę audinių sudètị. Eksperimentams naudoti žmogaus širdies audinio preparatai ex vivo. ŠLS, jungiamojo audinio (JA) ir miokardo (MK) lokalizacija preparate buvo preliminariai pažymèta gydytojo patologo. Po spektroskopinių tyrimų šios vietos buvo identifikuojamos histologiškai. Spektroskopiniai tyrimai atlikti spektrofotometru FLS920 (Edinburgh Instruments). Fluorescencija žadinta impulsiniu lazeriu, kurio spinduliuotés bangos ilgis $405 \mathrm{~nm}$. Iš spektroskopinių tyrimų nustatyta, kad mažiausiai trys fluoroforai yra atsakingi už širdies audinių fluorescenciją 430-550 nm srityje. Užregistruotos gyvavimo trukmès visų audinių yra panašios, todèl fluoroforai taip pat turètų būti tie patys. J̨vertinus fluoroforų inašus ị registruojamą fluorescencijos spektrą nustatyta, kad raumeninès kilmès audinių ŠLS ir MK sudètis yra panaši, o tarp ŠLS ir JA stebèti kiekybiniai skirtumai. 